\title{
Soil Assessment along Toposequences in Rural Northern Nigeria: A Geomedical Approach
}

\author{
Lena Hartmann, ${ }^{1}$ Marvin Gabriel, ${ }^{2}$ Yuanrong $\mathrm{Zhou}^{3}$ \\ Barbara Sponholz, ${ }^{4}$ and Heinrich Thiemeyer ${ }^{1}$ \\ ${ }^{1}$ Institute of Physical Geography, University of Frankfurt, Altenhöferallee 1, 60438 Frankfurt am Main, Germany \\ ${ }^{2}$ Institute of Physical Geography and Landscape Ecology, University of Hannover, Schneiderberg 50, 30167 Hannover, Germany \\ ${ }^{3}$ Physical and Environmental Science Department, University of Toronto Scarborough, Military Trail 1265, \\ Toronto, ON, Canada M1C 1A4 \\ ${ }^{4}$ Institute of Geography and Geology, University of Würzburg, Am Hubland, 97084 Würzburg, Germany
}

Correspondence should be addressed to Lena Hartmann; 1.hartmann@em.uni-frankfurt.de

Received 23 July 2013; Revised 25 February 2014; Accepted 7 March 2014; Published 27 March 2014

Academic Editor: Amaresh K. Nayak

Copyright (C) 2014 Lena Hartmann et al. This is an open access article distributed under the Creative Commons Attribution License, which permits unrestricted use, distribution, and reproduction in any medium, provided the original work is properly cited.

Case numbers of endemic Ca-deficiency rickets (CDR) have been reported to be alarmingly rising among children of subsistence farms in developing countries within the last 30 years. Fluoride toxicities in the environment are known to not be related to the disease. To investigate if, instead, CDR is caused by a nutrient deficiency in the environment, subsistence farms in an endemic CDR area near Kaduna, northern Nigeria, were investigated for bedrock, slope forms, soil types, and soil characteristics. The natural environment was investigated according to the World Reference Base, soil texture was analysed by pipette and sieving, and plant-available macronutrients were determined using barium-chloride or Ca-acetate-lactate extraction. The analyses showed that granite and slope deposits were the dominant parent materials. The typical slope forms and soil types were Lixisols and Acrisols on pediments, Fluvisols in river valleys, and Plinthosols and Acrisols on plains. Compared with West African background values, all of the soils had normal soil textures but were low in macronutrients. Comparisons to critical limits, however, showed that only the P concentrations were critically low, which are typical for savanna soils. A link between nutrient deficiency in soils and CDR in the Kaduna area was therefore considered unlikely.

\section{Introduction}

A high prevalence of $\mathrm{Ca}$ deficiency in children has been reported from rural communities southeast of Kaduna City, northern Nigeria, since the early 2000s. According to the local nongovernmental organisation Hope for the Village Child Foundation (HVCF), over 1000 children of small farms have already been registered as heavily affected by severe bone deformities in an area of $400 \mathrm{~km}^{2}$ [1]. The prevalence of Cadeficiency rickets (CDR) in this area was calculated to be around $5.0 \%$ among toddlers and adolescents aged from 15 months to 18 years [2] (Figure 1). Medical research in the rural Kaduna CDR area revealed a clear lack of Ca in the serum of the affected children $\left(<2.00 \mathrm{mmoll}^{-1}\right)[3-5]$.

Such cases of endemic CDR are particularly common in developing countries and have been reported in rising numbers, not only from Nigeria but also from countries such as Bangladesh, South Africa, or The Gambia [6, 7]. Previous research on the cause of CDR in these countries was mostly focused on biochemical, genetic, nutritional, and socioeconomic analyses [8-11]. However, the cause of the disease is still unknown up to now [12].

As CDR is often an endemic phenomenon, which is almost exclusively restricted to tropical areas, environmental conditions are currently discussed to be a predisposing factor for the CDR in developing countries. F toxicities, which are known to have caused comparable bone deformities among children living in countries such as India [13], were at first assumed to have also caused CDR. However, recent research on $\mathrm{F}$ concentrations in drinking water from different CDR areas in developing countries showed that the F levels in the water were too low to could have had any impact on bone strength [14]. 


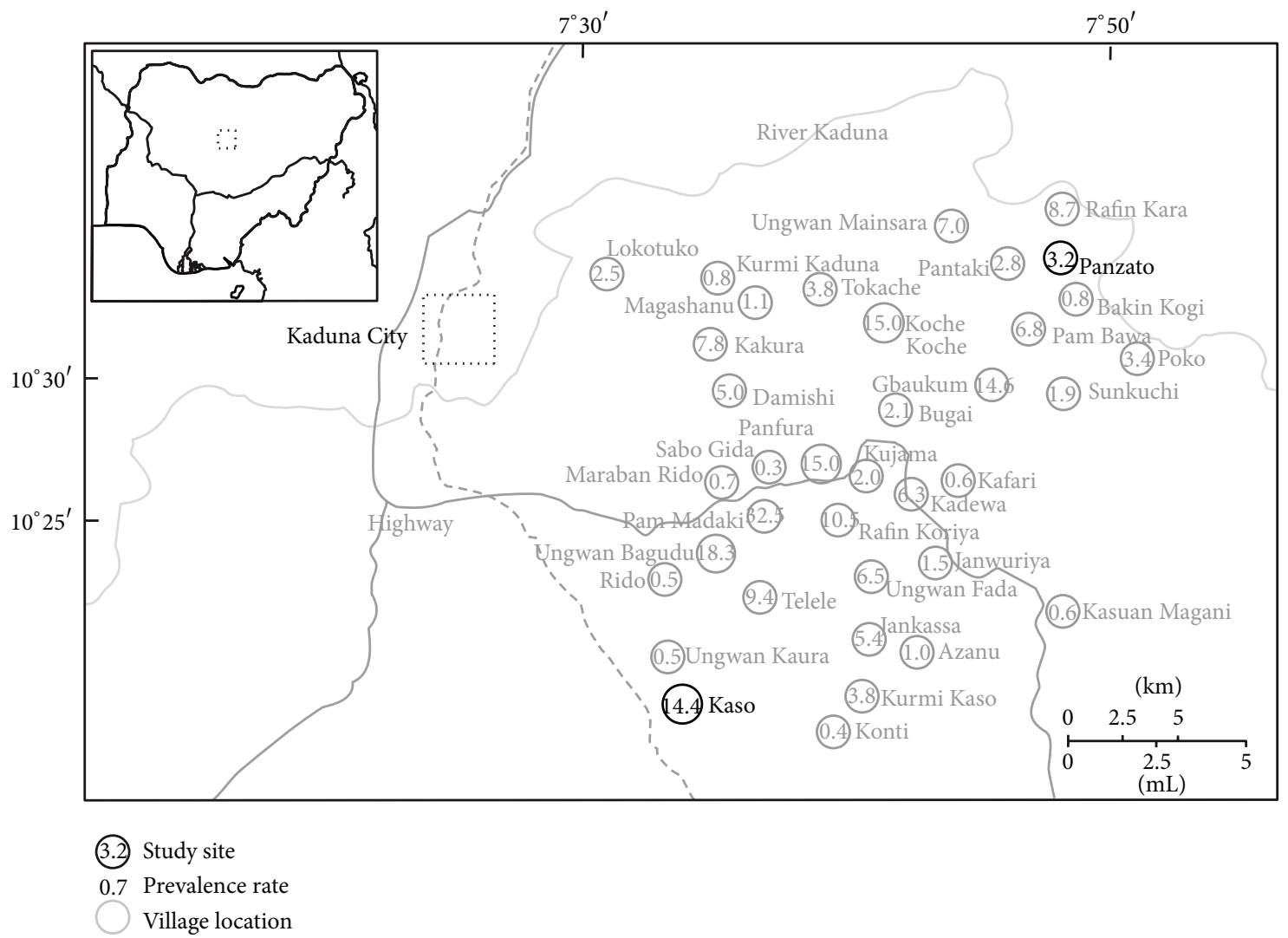

FIGURE 1: Study area and study sites.

Instead, pilot studies in rural Kaduna area showed that total Ca concentrations were very low in soils and food crops $[15,16]$, suggesting that a lack of $\mathrm{Ca}$ and other nutrients might be a predisposing factor to the CDR in the Kaduna area. Such relationship between nutrient deficiencies in soils and bone deformities in humans and animals is not new and has already been described from other areas $[17,18]$. To further examine the soils in the Kaduna CDR area for their plant-available Ca concentrations as well as to test the hypothesis if CDR areas are clearly impoverished in soil nutrients, environmental fieldwork was started in the Kaduna CDR area, northern Nigeria, in 2011.

\section{Material and Methods}

2.1. Study Area. The study area is located in northern Nigeria, southeast of Kaduna City, and covers an area of approximately $400 \mathrm{~km}^{2}$. Within this area, over 1000 children in 50 villages have been affected by CDR since the early 2000s. The average CDR prevalence rate in the Kaduna study area is $5.0 \%$, while the exact prevalence rates differ from village to village (Figure 1).

Detailed data on the environmental conditions of the Kaduna study area are limited to the Land Resource Studies, which were conducted in the 1970s by British and Nigerian scientists [26-29]. According to these studies, the area around Kaduna has a mean annual precipitation rate of $1300 \mathrm{~mm}$ and an average annual temperature of $25.6^{\circ} \mathrm{C}$. The morphology of the Kaduna study area is characterised by inselbergs, gently undulating plains, and small river valleys. The bedrock is of Proterozoic age and belongs to the Older Granite group [26]. The soils that have developed in the Kaduna area contain high contents of silt, which originated from Holocene Harmattan-dust deposits [30, 31]. Internationally accepted soil-classification work has not yet been conducted in the area [26]. The potential natural vegetation comprises savanna trees and grassland of the Northern Guinea Savanna type. Many parts of the Kaduna study area are agriculturally used, while both food crops and cash crops are cultivated. Besides maize (Zea mays) as the staple crop, also sorghum (Sorghum bicolor), yam (Dioscorea rotundata), manioc (Manihot esculenta), tomato (Solanum lycopersicum), and plantain (Musa acuminate) are grown on a small-farm level [28].

2.2. Field Methods. To determine representative spots for soil analyses, field observations and excessive hand auger analyses were conducted in the entire study area. Two representative study sites, one in the southwest around the village of Kaso, the other in the northeast around the village of Panzato, were then chosen for further analyses (Figure 1). In these study sites, soil profiles $(n=16)$ were dug along toposequences $(n=5)$. All analysed soil profiles, including A and B horizons, their respective topographical position, and the bedrock and parent materials were described according to the World 
Reference Base (WRB) Guidelines for Soil Description [32]. For laboratory analyses, bulk soil samples $(n=43)$ were taken from the primarily plant nutrition relevant $\mathrm{A}$ and $\mathrm{B}$ horizons of each soil profile and stored in polyethylene bags for a period of one month.

2.3. Laboratory Analyses. The soil samples taken from the A and $\mathrm{B}$ horizons were analysed for texture (pipette and sieving) according to Van Reeuwijk [33] and $\mathrm{pH}$ values were measured in $0.1 \mathrm{M} \mathrm{KCl}$ solution by electrometric measurement with WTW E56 combination electrode [34]. Organic carbon (OC) was determined by wet combustion, giving potassium dichromate $\left(\mathrm{K}_{2} \mathrm{Cr}_{2} \mathrm{O}_{7}\right)$ and sulfuric acid $\left(\mathrm{H}_{2} \mathrm{SO}_{4}\right)$ to the soil samples for titrimetric measurements [35] with Milton Roy spectral photometer C301. The plant-available concentrations of $\mathrm{P}$ were measured by spectral photometer Milton Roy C21 after adding $\mathrm{Ca}$ acetate lactate $\left(\mathrm{C}_{6} \mathrm{H}_{10} \mathrm{CaO}_{6}\right)$ and ammonium molybdate $\left(\left(\mathrm{NH}_{4}\right)_{2} \mathrm{MoO}_{4}\right)$ as a colouring agent. $\mathrm{Ca}$ acetate lactate was also used to determine the plant-available $\mathrm{K}$ concentration, while the eluate was measured by atomic absorption spectroscopy (AAS) Perkin Elmer Analyst 300 [36]. The plant-available concentrations of $\mathrm{Mg}$ and $\mathrm{Ca}$ as well as the potential cation exchange capacity (CEC) and base saturation (BS) were determined by adding buffered ( $\mathrm{pH}$ 8.1) barium chloride $\left(\mathrm{BaCl}_{2}\right)$ solution to the soil samples [37] before measuring with AAS Perkin Elmer Analyst 300. According to Ciesielski and Sterckeman [38], barium-chloride extractions show similar results as ammonium-acetate extraction, meaning that our laboratory measurements on soil nutrients and CEC are appropriate for WRB soil classification.

2.4. Soil Classification. By combining the results of the soil description, gained during the fieldwork, with those of the laboratory analyses, all soil profiles were classified according to the WRB classification system [39].

2.5. Soil Assessment. Based on calculations on median, 25th percentile, 75th percentile, minimum values, maximum values, and $t$-tests (one-sample, one-tailed) in Microsoft Excel, the chemical characteristics of the soils, including $\mathrm{pH}$ values, OC contents, $\mathrm{K}, \mathrm{Mg}$, Ca, and $\mathrm{P}$ concentrations as well as CEC and $\mathrm{BS}$ were compared to West African background values and critical limits [19-25]. $P$ values lower than 0.005 were considered to be statistically significant.

\section{Results}

3.1. Topography. Seven different morphological units were identified to be typical for the landscape of the Kaduna study area. These included inselbergs $(800 \mathrm{~m}$ above mean sea level), upper pediments $(670 \mathrm{~m}$ asl), lower pediments $(640 \mathrm{~m}$ asl), river valleys $(600 \mathrm{~m}$ asl), floodplains (550 $\mathrm{m}$ asl), lower plains (640 $\mathrm{m}$ asl), and upper plains (670 $\mathrm{m}$ asl). Since inselbergs and flood plains were not agriculturally used, soils found in these morphological units were not further analysed (Figure 2). Based on the evaluation of a topographical map [40], the distribution percentages of the analysed morphological units in the Kaduna study area, including upper pediment, lower pediment, river valley, lower plain, and upper plain positions, were estimated to be around $10 \%, 30 \%$, $20 \%, 30 \%$, and $10 \%$, respectively.

3.2. Parent Material. In two different areas around the villages of Kaso and Panzato, the parent materials of soil formation were determined in soil profiles. Accordingly, the two study sites were found to be underlain by granites, which were again covered by grus slope deposits in the upper pediment positions, grus slope deposits and river deposits in the lower pediment positions, river deposits in the river valleys, pisolite slope deposits and river deposits in the lower plain positions, and pisolite slope deposits in the upper plain positions (Table 1). Based on hand auger analyses, which were conducted in the entire study area before, grus slope deposits, pisolite slope deposits, and river deposits were the dominant parent materials for soil formation in the entire rural Kaduna area, covering around $30 \%, 30 \%$, and $40 \%$ of the landscape.

3.3. Physical Soil Characteristics. The soils of the study area were characterised by sandy or loamy subsoil horizons in most positions. Silt contents increased with depth, sometimes reaching up to $60 \%$. Depending on the topographical position of the soil profiles, the mean depth of the soils differed. Soils on the upper pediments, lower pediments, river valleys, lower plains, and upper plains had mean soil depths of $+40 \mathrm{~cm},+60 \mathrm{~cm},+60 \mathrm{~cm}, 50 \mathrm{~cm}$, and $55 \mathrm{~cm}$, respectively (Table 1).

3.4. Chemical Soil Characteristics. The soils of the study area were acidic, with $\mathrm{pH}$ values ranging from 4 to 5 . The concentrations of OC were always lower than $1.3 \%$ and were highest in the A horizons. The plant-available soil nutrients were present in the order $\mathrm{Ca}>\mathrm{Mg}>\mathrm{K}>\mathrm{P}$. The $\mathrm{Ca}$ concentrations were between 0.4 and $5.6 \mathrm{cmol} \mathrm{kg}^{-1}$, the $\mathrm{Mg}$ concentrations were between 0.0 and $1.6 \mathrm{cmol} \mathrm{kg}^{-1}$, the $\mathrm{K}$ concentrations ranged between 0.0 and $0.4 \mathrm{cmol} \mathrm{kg}^{-1}$, and the $\mathrm{P}$ concentrations were between 0.0 and $8.0 \mathrm{mg} \mathrm{kg}^{-1}$. The concentrations of $\mathrm{Ca}, \mathrm{Mg}$, and $\mathrm{K}$ increased with depth in the pediment soils but decreased with depth in the river valley and plain soils. The $\mathrm{P}$ concentrations decreased with depth in all the soils. The BS was between 5.2 and $65.8 \%$ and decreased with depth in all the soils. The CEC ranged between 2.9 and $13.5 \mathrm{cmol} \mathrm{kg}^{-1}$. A clear increase of CEC with depth was found in all the soils (Table 2).

3.5. Soil Classification. Depending on topography and parent materials, five main soil types were identified in the Kaduna study area. On the upper pediments, where slopes ranged between $1^{\circ}$ and $3^{\circ}$, soils had argic horizons, developed on grus slope deposits, a BS average above $50 \%$ as well as a high CEC, and were thus classified as Lixisols. On the lower pediments, which had slopes between $1^{\circ}$ and $4^{\circ}$, grus slope deposits and river deposits were the main parent materials of soil formation. In these positions, soils always had a diagnostic argic horizon with a BS averagely lower than $50 \%$, a high CEC, and were thus classified as Acrisols. In the river valleys, where slopes were lower than $1^{\circ}$, river deposits were the dominant parent material. Where soils 


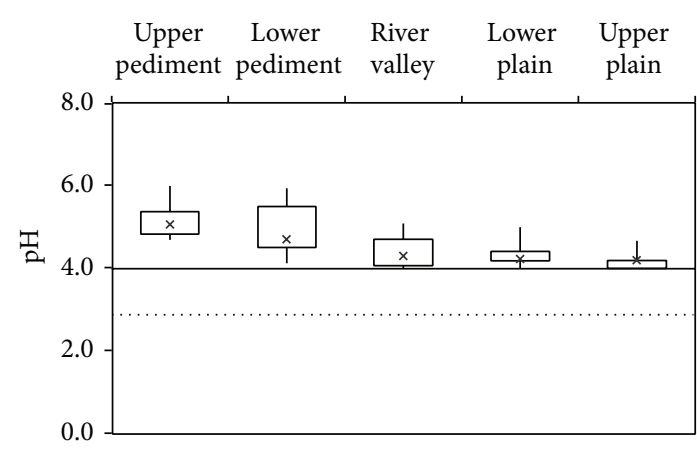

(a)

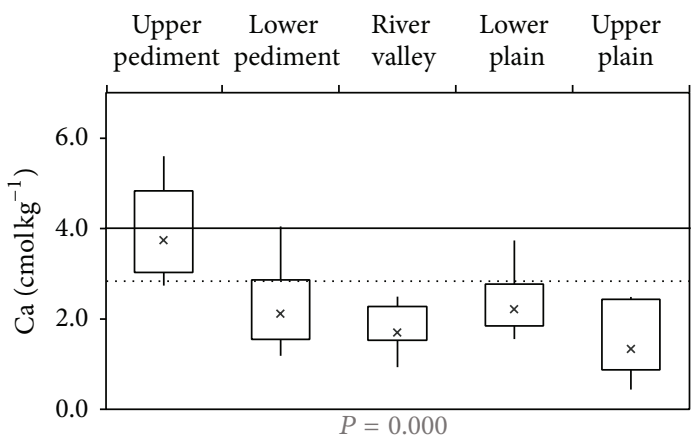

(c)

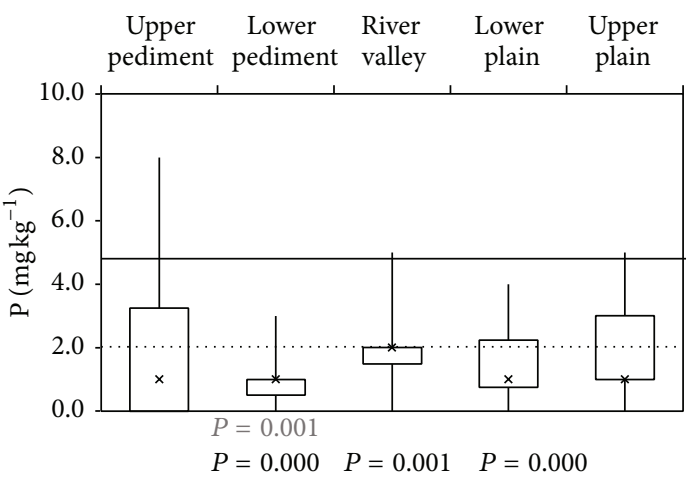

(e)

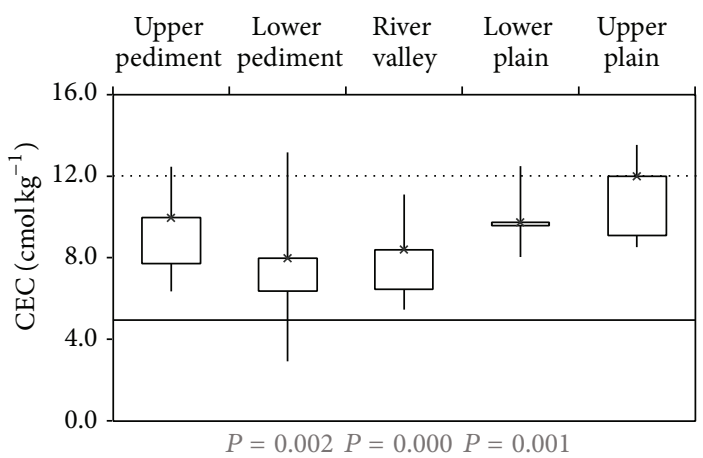

(g)

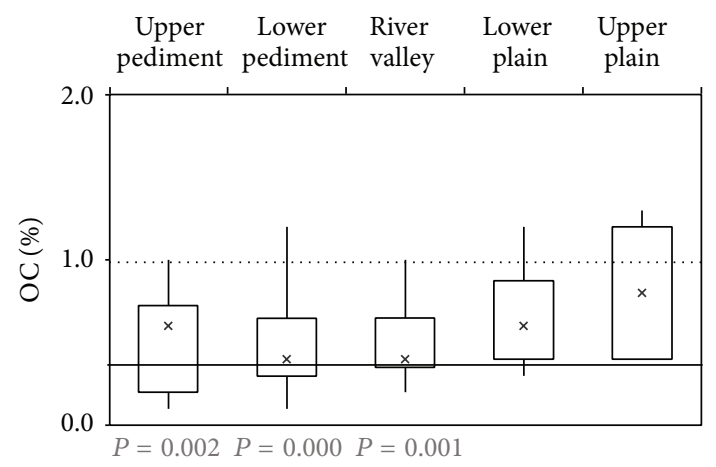

(b)

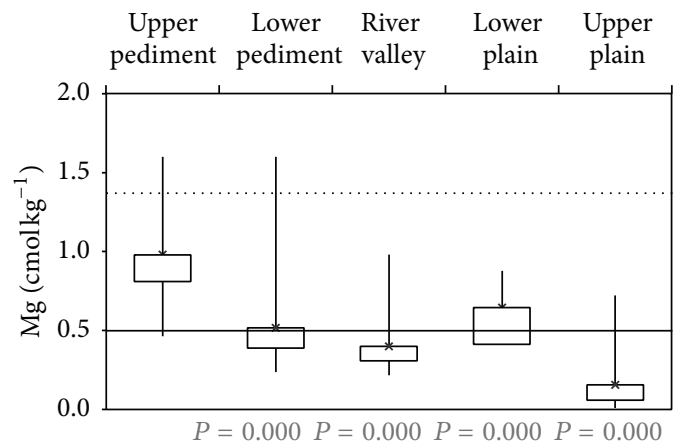

(d)

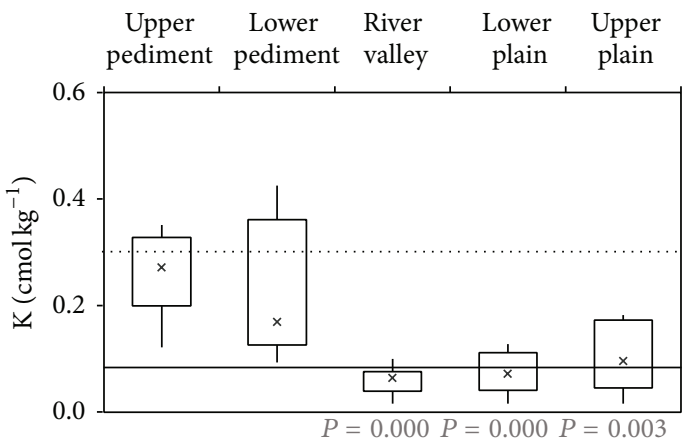

(f)

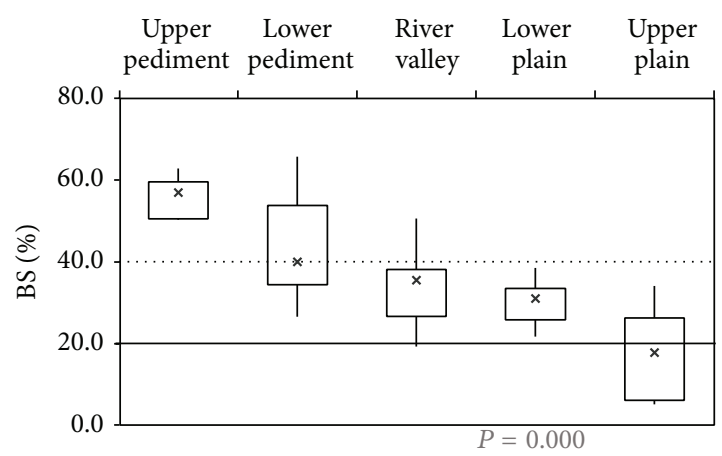

(h)

Figure 2: pH values, OC contents, $\mathrm{Ca}, \mathrm{Mg}, \mathrm{K}$, and $\mathrm{P}$ concentrations as well as BS and CEC in soils of the Kaduna study area compared to West African background levels and critical limits. Boxplot diagrams show chemical characteristics of the Kaduna study area soils that have developed on upper pediments, lower pediments, river valleys, lower plains, and upper plains, respectively. Dotted lines represent West African background values, while solid lines show the critical limits both as given by Jones and Wild [19], Landon [20], Vanlauwe et al. [21], Raji et al. [22], Agbenin and Yakubu [23], Esu and Ojanuga [24], and Valette and Ibanga [25]. Grey $P$ values indicate statistically significant differences between the $\mathrm{pH}, \mathrm{OC}, \mathrm{Ca}, \mathrm{Mg}, \mathrm{K}, \mathrm{P}, \mathrm{BS}$, and CEC of the soils in the Kaduna study area and the West African background values. Black $P$ values indicate statistically significant differences between the Kaduna soil fertility parameters and the critical limits. 
TABLE 1: Physical soil characteristics of the soils in the Kaduna study area.

\begin{tabular}{|c|c|c|c|c|c|c|c|}
\hline Morphological unit & it Parent material & Soil type & Horizon & Depth $(\mathrm{cm})$ & $\begin{array}{c}\text { Sand } \\
(2000-63 \mu \mathrm{m}) \\
(\%)\end{array}$ & $\begin{array}{c}\text { Silt } \\
(63-2 \mu \mathrm{m}) \\
(\%)\end{array}$ & $\begin{array}{c}\text { Clay } \\
(<2 \mu \mathrm{m}) \\
(\%)\end{array}$ \\
\hline \multirow{8}{*}{ Upper pediment } & \multirow{8}{*}{ Grus slope deposits } & \multirow{3}{*}{$\begin{array}{l}\text { Haplic Lixisols } \\
\text { (chromic) }\end{array}$} & Ap & $0-5$ & 55 & 31 & 14 \\
\hline & & & $\mathrm{Bt}^{*}$ & $5-55$ & 37 & 22 & 41 \\
\hline & & & $2 \mathrm{Btw}$ & $55+$ & 31 & 30 & 39 \\
\hline & & \multirow{3}{*}{$\begin{array}{l}\text { Haplic Lixisols } \\
\text { (colluvic) }\end{array}$} & Ap & $0-20$ & 65 & 24 & 11 \\
\hline & & & $2 \mathrm{Btw}^{*}$ & $20-50$ & 39 & 23 & 38 \\
\hline & & & 2Bwo & $50+$ & 45 & 20 & 35 \\
\hline & & \multirow{2}{*}{ Haplic Lixisols } & Ap & $0-10$ & 62 & 25 & 13 \\
\hline & & & $\mathrm{Bt}^{*}$ & $10+$ & 51 & 22 & 27 \\
\hline \multirow{11}{*}{ Lower pediment } & \multirow{11}{*}{$\begin{array}{l}\text { Grus slope deposits and } \\
\text { river deposits }\end{array}$} & \multirow{4}{*}{$\begin{array}{l}\text { Haplic Acrisols } \\
\text { (arenic) }\end{array}$} & Ap & $0-15$ & 61 & 30 & 9 \\
\hline & & & Bo & $15-30$ & 56 & 25 & 19 \\
\hline & & & Bto* $^{*}$ & $30-50$ & 41 & 27 & 32 \\
\hline & & & $2 \mathrm{Bo}$ & $50+$ & 37 & 32 & 31 \\
\hline & & \multirow{3}{*}{ Haplic Acrisols } & Ap & $0-10$ & 27 & 46 & 27 \\
\hline & & & Bto* & $10-45$ & 16 & 39 & 45 \\
\hline & & & Bwo & $45+$ & 16 & 40 & 44 \\
\hline & & \multirow{4}{*}{$\begin{array}{l}\text { Haplic Acrisols } \\
\text { (arenic) }\end{array}$} & Ap & $0-10$ & 58 & 36 & 6 \\
\hline & & & $\mathrm{Bl}$ & $10-30$ & 61 & 33 & 6 \\
\hline & & & $\mathrm{Bt}^{*}$ & $30-80$ & 44 & 27 & 29 \\
\hline & & & $2 \mathrm{Bt}$ & $80+$ & 41 & 28 & 31 \\
\hline \multirow{7}{*}{ River valley } & \multirow{7}{*}{ River deposits } & \multirow{2}{*}{$\begin{array}{l}\text { Gleyic Fluvisols } \\
\text { (dystric, siltic) }\end{array}$} & Ap & $0-20$ & 13 & 62 & 25 \\
\hline & & & Bsg* & $20-60+$ & 15 & 62 & 23 \\
\hline & & \multirow{2}{*}{$\begin{array}{l}\text { Gleyic Fluvisols } \\
\text { (dystric, siltic) }\end{array}$} & Ap & $0-15$ & 25 & 44 & 31 \\
\hline & & & Bog* & $15-45+$ & 13 & 63 & 24 \\
\hline & & \multirow{3}{*}{$\begin{array}{l}\text { Haplic Fluvisols } \\
\text { (arenic) }\end{array}$} & Ap & $0-20$ & 58 & 29 & 13 \\
\hline & & & $\mathrm{Bg}$ & $20-35$ & 52 & 33 & 15 \\
\hline & & & $2 \mathrm{Bsg}^{*}$ & $35-80+$ & 60 & 20 & 20 \\
\hline \multirow{8}{*}{ Lower plain } & \multirow{8}{*}{$\begin{array}{l}\text { Pisolite slope deposits } \\
\text { and river deposits }\end{array}$} & \multirow{3}{*}{$\begin{array}{l}\text { Pisoplinthic Acrisols } \\
\text { (chromic) }\end{array}$} & Ap & $0-15$ & 31 & 46 & 23 \\
\hline & & & Bto* & $15-45$ & 20 & 37 & 43 \\
\hline & & & 2Bwo & $45-55+$ & 18 & 40 & 42 \\
\hline & & \multirow{2}{*}{$\begin{array}{l}\text { Gleyic Acrisols } \\
\text { (siltic) }\end{array}$} & Ap & $0-15$ & 19 & 62 & 19 \\
\hline & & & Bto* $^{*}$ & $15-25$ & 20 & 62 & 18 \\
\hline & & \multirow{3}{*}{$\begin{array}{l}\text { Pisoplinthic Acrisols } \\
\text { (chromic) }\end{array}$} & Ahc & $0-10$ & 29 & 42 & 29 \\
\hline & & & Bto* $^{*}$ & $10-30$ & 28 & 38 & 34 \\
\hline & & & $2 \mathrm{Bw}$ & $30-60+$ & 22 & 32 & 46 \\
\hline \multirow{5}{*}{ Upper plain } & \multirow{5}{*}{ Pisolite slope deposits } & \multirow{2}{*}{$\begin{array}{l}\text { Haplic Plinthosols } \\
\text { (dystric) }\end{array}$} & Ap & $0-15$ & 43 & 24 & 33 \\
\hline & & & $\mathrm{Bv}^{*}$ & $15-30$ & 43 & 35 & 22 \\
\hline & & \multirow{3}{*}{$\begin{array}{l}\text { Haplic Plinthosols } \\
\text { (hyperdystric, clayic) }\end{array}$} & Ahc & $0-5$ & 21 & 37 & 42 \\
\hline & & & $\mathrm{Btv}^{*}$ & $5-30$ & 18 & 31 & 51 \\
\hline & & & Bov & $30-80$ & 21 & 31 & 48 \\
\hline
\end{tabular}

${ }^{*}$ Diagnostic horizons.

were influenced by groundwater, soils were classified as Fluvisols. On the lower plains, which had slopes between $1^{\circ}$ and $2^{\circ}$, soils had developed in pisolite slope deposits and river deposits. With diagnostic argic horizons and a typically low BS, soils were classified as Pisoplinthic Acrisols. Only where the groundwater conditions were increasing, soils were classified as Gleyic Acrisols. On the upper plain, where slopes were lower than $1^{\circ}$, soils had developed on pisolites slope deposits. These soils were classified as Plinthosols. Assuming that the differences in the soil type were consistently caused by differences in morphology and parent material, the distribution percentages of Lixisols, Acrisols, Fluvisols, and 
TABLE 2: Chemical soil characteristics of the soils of the study area.

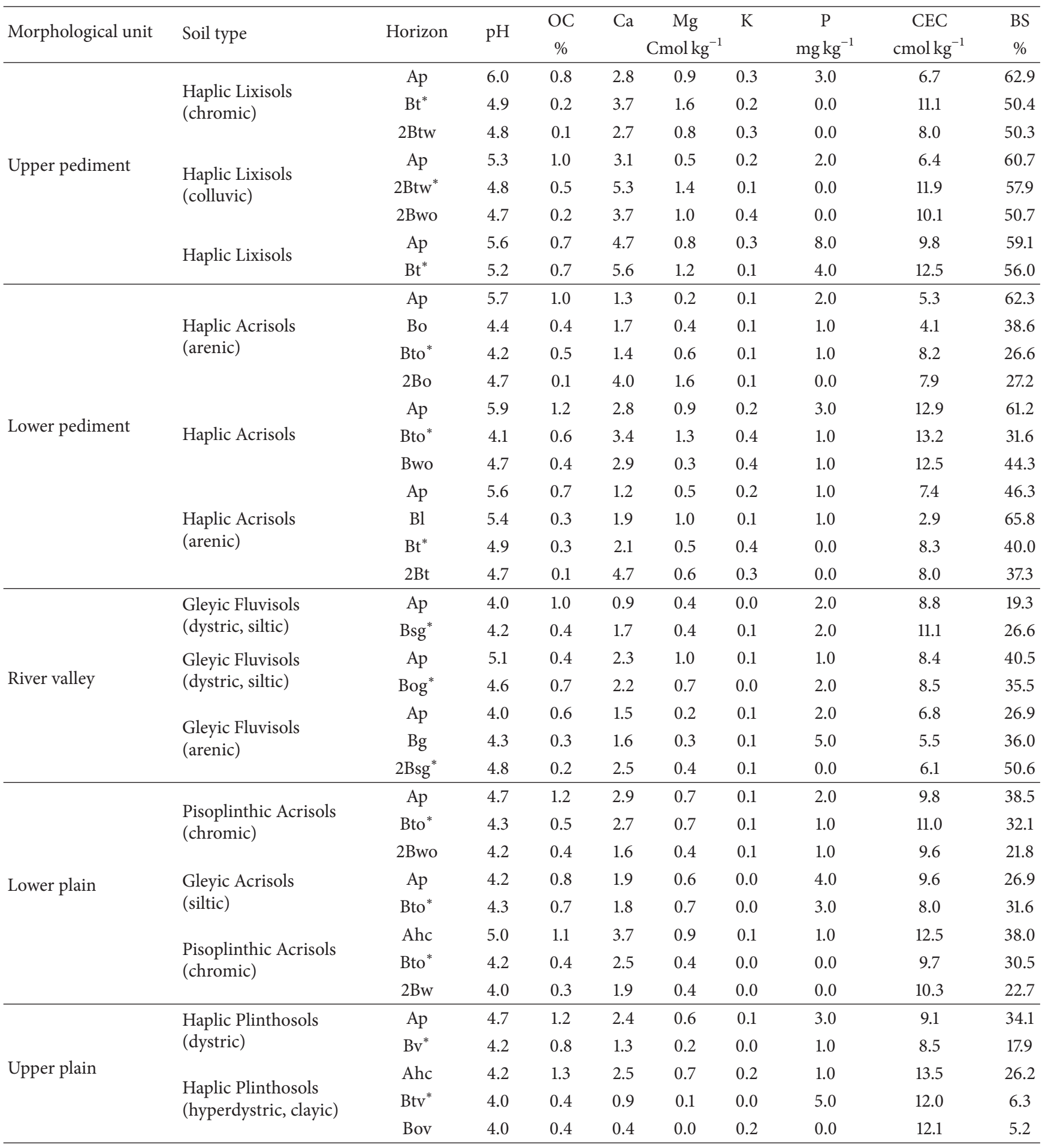

${ }^{*}$ Diagnostic horizons.

Plinthosols were estimated to be around 10\%, 60\%, 20\%, and $10 \%$, respectively, in the Kaduna study area.

3.6. Soil Assessment. To evaluate the fertility of the soils in the Kaduna study area, all chemical characteristics measured in the soils were compared to West African background values as given by Jones and Wild [19], Landon [20], Vanlauwe et al. [21], Raji et al. [22], Agbenin and Yakubu [23], Esu and Ojanuga [24], and Valette and Ibanga [25]. According to these comparisons, only the $\mathrm{pH}$ values of the soils in the Kaduna study area were higher than the West African background. All the other parameters, including OC contents, $\mathrm{Ca}, \mathrm{Mg}, \mathrm{K}$, and 
$\mathrm{P}$ concentrations, and BS and CEC, were lower than the West African background values. In some positions and soils, the difference to the West African background values even was of statistical significance. In the pediment soils, OC contents, $\mathrm{Mg}$ and $\mathrm{P}$ concentrations, and CEC were significantly lower than the West African background values, in the river valley soils, OC contents, $\mathrm{Ca}, \mathrm{Mg}$, and $\mathrm{K}$ concentrations, and CEC were significantly lower than the West African background value, and in the plain soils, $\mathrm{Mg}$ and $\mathrm{K}$ concentrations as well as CEC and BS were significantly lower than the West African background values (Figure 2).

Compared to critical limits as given by the same authors [19-25], however, only the plant-available P concentrations were significantly low, especially in the soils which had developed in the lower pediment, river valley, and lower plain positions. All the other parameters, including OC contents, $\mathrm{Ca}, \mathrm{Mg}$, and $\mathrm{K}$ concentrations, and $\mathrm{BS}$ and $\mathrm{CEC}$ were found to be high enough in all the soils to ensure a healthy development of the most common crops (Figure 2).

\section{Discussion}

The herein presented study was conducted to analyse a possible relationship between endemic cases of CDR in small farmer children living near Kaduna City and a Ca or nutrient deficiency in the soils of this area. The analyses showed that the typical soil types in the study area were Lixisols on grus slope deposits in the upper pediment positions, Acrisols on grus slope deposits and river deposits in the lower pediment positions, Fluvisols on river deposits in the river valleys, Pisoplinthic Acrisols on pisolite slope deposits and river deposits in the lower plains, and Plinthosols on pisolite slope deposits in the upper plains. The distribution of these soils was estimated to be approximately $10 \%, 60 \%, 20 \%$, and $10 \%$, respectively, in the Kaduna study area. According to Møberg and Esu [41], Vanlauwe et al. [21], and Raji et al. [22], such soil types are quite typical for West Africa as well as regions north of the Kaduna study area, where no cases of CDR have been reported up to now $[8,10]$.

Apart from the soil types and their distributions, the physical characteristics of the soils in the Kaduna study area were analysed. The soils in this area were found to have a mean thickness of $50 \mathrm{~cm}$ and tended to have sandy to loamy topsoil, loamy subsoil, and remarkably high contents of silt in almost all the analysed horizons. According to Bennett [30], Bennett et al. [26], and Jones and Wild [19], such textures are typical for soils in West Africa as well as in regions north of the study area and are thus not restricted to CDR areas only.

An assessment of the soils based on the statistical comparison with the West African background values showed that the soils of the Kaduna study area have low concentrations of plant-available macronutrients, a low BS and a low CEC. The lowest concentrations of these parameters were often found in the soils that had developed in the river valleys or the plains. Only the $\mathrm{pH}$ values were higher in the soils of the Kaduna study area than other soils that are typically found in West Africa [19-25].

According to Schulin et al. [42], high $\mathrm{pH}$ values are known to inhibit micronutrient availability. Since a lack of micronutrients is known to cause hidden hunger and is even discussed to be a possible cause of CDR [43-46], the high $\mathrm{pH}$ values might be interpreted as an indicator of micronutrient deficiency in the soils of the Kaduna study area. Further analyses should be conducted on the plant-available concentrations of micronutrients in soils and food crops to check their relationship to the CDR in the Kaduna study area.

Apart from the $\mathrm{pH}$ levels, $\mathrm{K}$ concentrations were found to be significantly lower in the soils of the river valleys and plains than the West African background values. These deficiencies might be caused by the low K concentrations in the pisolites, which serve as the parent materials of soil formation in these positions. In the pediment's soils, where granites containing K-bearing minerals, such as mica, formed the bedrock [16, 26], $\mathrm{K}$ was found to be abundant. However, a link between $\mathrm{K}$ deficiency in soil and impaired bone mineralisation in children can generally be ruled out since $\mathrm{K}$ deficiency is not known to have any influence on bone structure [43].

Apart from the $\mathrm{K}$ concentrations, also the $\mathrm{P}$ concentrations were found to be significantly lower than the West African background values and in some positions were even lower than the critical limits. According to the analyses by Bakare-Odunola et al. [15], not only the soils but also the food crops that are cultivated in the Kaduna study area have low $\mathrm{P}$ contents. However, P contents in food crops are crucial for bone strength only when P contents are significantly elevated but not when the $\mathrm{P}$ contents are significantly decreased. Such interactions between $\mathrm{P}$ oversupply and a weakened bone structure are especially found in combination with low dietary Ca intake [45]. P deficiencies, on the other hand, are common throughout many savanna regions and are not restricted to CDR areas only $[19,20]$. As a result, $\mathrm{P}$ deficiency found in the soils and crops of the Kaduna study area was assumed not to be a predisposing factor for the CDR in this region.

\section{Conclusions}

The herein presented study was conducted to analyse the relationship between Ca deficiency in CDR children of small farms in rural areas southeast of Kaduna City, northern Nigeria, and a lack of $\mathrm{Ca}$ and other nutrients in the soils of this area. Analyses on the environmental conditions of the endemic CDR area near Kaduna City showed that the area is underlain by granites which are again covered by different slope deposits. The main soil types in the Kaduna study area were Lixisols, Acrisols, Plinthosols, and Fluvisols, which are the typical soil types of the West African savanna. Compared to West African background values, the soils in the Kaduna study area had high $\mathrm{pH}$ values but had low OC contents, were low in $\mathrm{Ca}, \mathrm{Mg}, \mathrm{K}$, and $\mathrm{P}$, and had a low CEC and BS. The soils that had developed in the river valleys and on the plains had the lowest soil fertility. Compared to critical limits, however, the plant-available amounts of the macronutrients were found to be sufficient for healthy crop growth, except that the $\mathrm{P}$ concentrations were critically low. However, since $\mathrm{P}$ deficiency is found in many parts of the West African savanna and is not restricted to CDR areas and there are no known influences of P deficiency on human bone strength, 
a link between $\mathrm{P}$ deficiency in soils and CDR in human was considered unlikely. Further analyses should take the measurement of micronutrient concentrations in the soils of CDR areas into consideration and should also examine their contents in the local food crops.

\section{Highlights}

In an area of endemic $\mathrm{Ca}$-deficiency rickets (CDR) in northern Nigeria, Lixisols, Acrisols, Plinthosols, and Fluvisols were identified to be the dominant soil types. Compared with West African background values, all the soil types had low plant-available macronutrient concentrations. Compared with critical limits, however, only $\mathrm{P}$ concentrations were critically low. A link between nutrient deficiency in soils and CDR in children was considered unlikely.

\section{Conflict of Interests}

The authors declare that they have no conflict of interests regarding the publication of this paper.

\section{Acknowledgments}

The authors are grateful to the staff of the nongovernmental organization Hope for the Village Child Foundation, especially Sister Rita Schwarzenberger, Hakuri Matala, and Michael Ogundele, for having supported their research in Nigeria. Special thanks are due to all the local people from the rural Kaduna area who have supported the research stay in the communities. The authors are obliged to Doris Bergmann-Dörr and Dagmar Schneider of the Soil Science Laboratories of the University of Frankfurt for their accurate laboratory analyses. Research was funded by the Vereinigung der Freunde und Förderer of the University of Frankfurt, the German Academic Exchange Service (DAAD), and the International Bureau of the German Federal Ministry of Education and Research (BMBF).

\section{References}

[1] Hope for the Village Child Foundation (HVCF), The HVCF Centre, Collins, Kaduna, Nigeria, 2010.

[2] Hope for the Village Child Foundation (HVCF), The Number of Rickets Cases in Villages East of Kaduna City in the Year 2011, Kaduna, Nigeria, 2011.

[3] W. K. Emmert, Rachitis-ähnliche Symptome bei nigerianischen Kindern aus der Ethnie der Gbagyi in der südwestlichen Region Kadunas: Identifizierung des biochemischen Defekts, Sammeln von epidemiologischen Daten und Beschreibung des klinischen Bildes [Ph.D. thesis], University of Würzburg, Würzburg, Germany, 2009.

[4] C. Kitz, A. Stich, R. Ebert, F. Jakob, P. Raab, and B. Sponholz, "Rickets in Nigeria. Do geological and genetic factors play a role besides extreme calcium deficiency?" Flug und Reisemedizin, vol. 16, no. 2, pp. 76-80, 2009.

[5] O. A. Couppis, W. K. Emmert, C. Kitz, W. Vant Hoff, W. M. Drake, and A. Stich, "The metabolic basis of a severe ricketslike deformity in Nigerian children," Endocrine Abstracts, vol. 12, p. 14, 2006.
[6] V. Braithwaite, L. M. A. Jarjou, G. R. Goldberg, H. Jones, J. M. Pettifor, and A. Prentice, "Follow-up study of Gambian children with rickets-like bone deformities and elevated plasma FGF23: possible aetiological factors," Bone, vol. 50, no. 1, pp. 218-225, 2012.

[7] T. Craviari, J. M. Pettifor, T. D. Thacher, C. Meisner, J. Arnaud, and P. R. Fischer, "Rickets: an overview and future directions, with special reference to Bangladesh: a summary of the rickets convergence group meeting, Dhaka, 26-27 January 2006," Journal of Health, Population and Nutrition, vol. 26, no. 1, pp.112-121, 2008.

[8] A. Bereket, "Rickets in developing countries," in VitamIn D and Rickets, Z. Hochberg, Ed., pp. 220-232, Karger, Basel, Switzerland, 2003.

[9] A. Prentice, "Nutritional rickets around the world," The Journal of Steroid Biochemistry and Molecular Biology, vol. 136, pp. 2012206, 2013.

[10] T. D. Thacher, P. R. Fischer, M. A. Strand, and J. M. Pettifor, "Nutritional rickets around the world: causes and future directions," Annals of Tropical Paediatrics, vol. 26, no. 1, pp. 1-16, 2006.

[11] G. F. Combs Jr., N. Hassan, N. Dellagana et al., "Apparent efficacy of food-based calcium supplementation in preventing rickets in Bangladesh," Biological Trace Element Research, vol. 121, no. 3, pp. 193-204, 2008.

[12] I. Zinßer, Polymorphisms of the vitamin D receptor gene and the 24-hydroxylase enzyme in Nigerian children with rickets [Ph.D. thesis], University of Würzburg, Würzburg, Germany, 2012.

[13] M. Teotia, S. P. S. Teotia, and K. P. Singh, "Endemic chronic fluoride toxicity and dietary calcium deficiency interaction syndromes of metabolic bone disease and deformities in India: year 2000," Indian Journal of Pediatrics, vol. 65, no. 3, pp. 371381, 1998.

[14] J. M. Pettifor, P. R. Fischer, T. D. Thacher, J. Arnaud, and C. A. Meissner, "Dietary calcium deficiency \& rickets," Indian Journal of Medical Research, vol. 128, no. 5, pp. 673-674, 2008.

[15] M. T. Bakare-Odunola, T. Kalik-Zik, R. A. Odunola, and K. Bello-Mustapha, "Nutritional assessment of the diets in rickets prevalent communities in Kaduna State of Nigeria," International Journal of Medical Sciences, vol. 4, no. 4, pp. 110$114,2012$.

[16] L. Hartmann and B. Sponholz, "Spatial distribution of calcium in food, water and soil and its possible influence on rickets disease in Northern Nigeria," Environmental Geochemistry and Health, vol. 34, no. 3, pp. 503-512, 2012.

[17] L. Zongping, "Studies on rickets and osteomalacia in Bactrian camels (Camelus bactrianus)," Veterinary Journal, vol. 169, no. 3, pp. 444-453, 2005.

[18] J. Pooley, Nutrient deficiencies in soils of the Mseleni area, Kwazulu-Natal [M.S. thesis], Stellenbosch University, Cape Town, South Africa, 2003.

[19] M. J. Jones and A. Wild, Soils of the West African Savanna. The Maintenance and Improvement of Their Fertility, Commonwealth Agricultural Bureaux, Slough, UK, 1975.

[20] J. R. Landon, Ed., Booker Tropical Soil Manual: A Handbook for Soil Survey and Agricultural Land Evaluation in the Tropics and Subtropics, Longman Scientific and Technical, New York, NY, USA, 1991.

[21] B. Vanlauwe, J. Diels, O. Lyasse et al., "Fertility status of soils of the derived savanna and Northern Guinea savanna and response to major plant nutrients, as influenced by soil type and 
land use management," Nutrient Cycling in Agroecosystems, vol. 62, no. 2, pp. 139-150, 2002.

[22] B. A. Raji, W. B. Malgwi, F. R. Berding, and V. O. Chude, "Integrating indigenous knowledge and soil science approaches to detailed soil survey in Kaduna State, Nigeria," Journal of Soil Science and Environmental Management, vol. 2, no. 3, pp. 66-73, 2011.

[23] J. O. Agbenin and S. Yakubu, "Potassium-calcium and potassium-magnesium exchange equilibria in an acid savanna soil from northern Nigeria," Geoderma, vol. 136, no. 3-4, pp. 542554, 2006.

[24] I. E. Esu and A. G. Ojanuga, "Morphological, physical and chemical characteristics of Alfisol in the Kaduna area of Nigeria," Samaru Journal of Agricultural Research, vol. 3, pp. 39-49, 1985.

[25] J. Valette and I. J. Ibanga, The Detailed Survey of the Experimental Farm of the Institute For Agricultural Research, Samaru, Zaria, Nigeria, Institute for Agricultural Research, Zaria, Nigeria, 1984.

[26] J. G. Bennett, A. A. Hutcheon, W. B. Kerr, J. E. Mansfield, and L. J. Rackham, Environmental Aspects of the Kaduna Plains, Land Forms and Soils, Land Resources Report 19, Land Resources Division, Surrey, UK, 1977.

[27] J. G. Bennett, A. A. Hutcheon, W. B. Kerr, J. E. Mansfield, and L. J. Rackham, Environmental Aspects of the Kaduna Plains, Land Systems, Land Resources Report 19, Land Resources Division, Surrey, UK, 1977.

[28] A. Blair Rains, R. M. Lawton, J. E. Mansfield, and R. Rose Innes, Environmental Aspects of the Kaduna Plains, Climate and Vegetation, Land Resources Report 19, Land Resources Division, Surrey, UK, 1977.

[29] J. R. D. Wall, Agricultural Development Possibilities, vol. 5B of Land Resource Study 29, The Kaduna plains, Land Resources Development Centre, Surrey, UK, 1979.

[30] J. G. Bennett, "Aeolian deposition and soil parent materials in northern Nigeria," Geoderma, vol. 24, no. 3, pp. 241-255, 1980.

[31] L. Herrmann, R. Jahn, and K. Stahr, "Identification and quantification of dust additions in peri-Saharan soils," in The Impact of Desert Dust Across the Mediterranean, S. Guerzoni and R. Chester, Eds., pp. 173-182, Groningen, The Netherlands, 1996.

[32] IUSS Working Group WRB, Guidelines Ffor Soil Description, FAO, Rome, Italy, 4th edition, 2006.

[33] L. P. Van Reeuwijk, Procedures for Soil Analyses, ISRIC, Wageningen, Germany, 6th edition, 2012.

[34] K. J. Meiwes, "Chemische Untersuchungsverfahren für Mineralboden, Auflagehumus, und Wurzeln zur Charakterisierung und Bewertung der Versauerung in Waldböden," Berichte des Forschungszentrums Waldökosysteme/Waldsterben, vol. 7, pp. 167, 1984.

[35] DIN 19684, Determination of the Humus Content of a Soil, Part 2, Deutsches Institut für Normung, Berlin, Germany, 1977.

[36] H. Schüller, "Die CAL-Methode, eine neue Methode zur Bestimmung des pflanzenverfügbaren Phosphates in Böden," Zeitschrift für Pflanzenernährung und Bodenkunde, vol. 123, pp. 48-63, 1979.

[37] DIN 19684, Determination of Exchange Capacity of a Soil and of Amounts of Exchangeable Cations, Part 8, Deutsches Institut für Normung, Berlin, Germany, 1977.

[38] H. Ciesielski and T. Sterckeman, "A comparison between three methods for the determination of cation exchange capacity and exchangeable cations in soils," Agronomy, Agriculture and Environment, vol. 17, no. 1, pp. 9-16, 1997.
[39] IUSS Working Group WRB, World Reference Base for Soil Resources 2006, FAO, Rome, Italy, 1st edition, 2007.

[40] Federal Survey Nigeria, Kaduna, sheet 32, Topographical Map, 1:250.000, Federal Survey Nigeria, Kaduna, Nigeria, 1967.

[41] J. P. Møberg and I. E. Esu, "Characteristics and composition of some savanna soils in Nigeria," Geoderma, vol. 48, no. 1-2, pp. 113-129, 1991.

[42] R. Schulin, A. Johnson, and E. Frossard, "Trace element deficient soils," in Trace Elements in Soils, P. Hooda, Ed., pp. 175-197, Blackwell, Chichester, UK, 2010.

[43] G. F. Combs Jr. and N. Hassan, "The Chakaria food system study: household-level, case-control study to identify risk factor for rickets in Bangladesh," European Journal of Clinical Nutrition, vol. 59, no. 11, pp. 1291-1301, 2005.

[44] S. J. Fairweather-Tait, Y. Bao, M. R. Broadley et al., "Selenium in human health and disease," Antioxidants and Redox Signaling, vol. 14, no. 7, pp. 1337-1383, 2011.

[45] F. Jakob, L. Seefried, C. Kitz et al., "Trace elements and bone," in Nutritional Influences on Bone Health, P. Burckhardt, B. Dawson-Hughes, and C. Weaver, Eds., pp. 81-86, London, UK, 2010.

[46] C. Lamberg-Allardt, H. Karp, and V. Kemi, "Phosphorus and bone," in Nutritional Influences on Bone Health, P. Burckhardt, B. Dawson-Hughes, and C. Weaver, Eds., pp. 87-97, Springer, New York, NY, USA, 2010. 

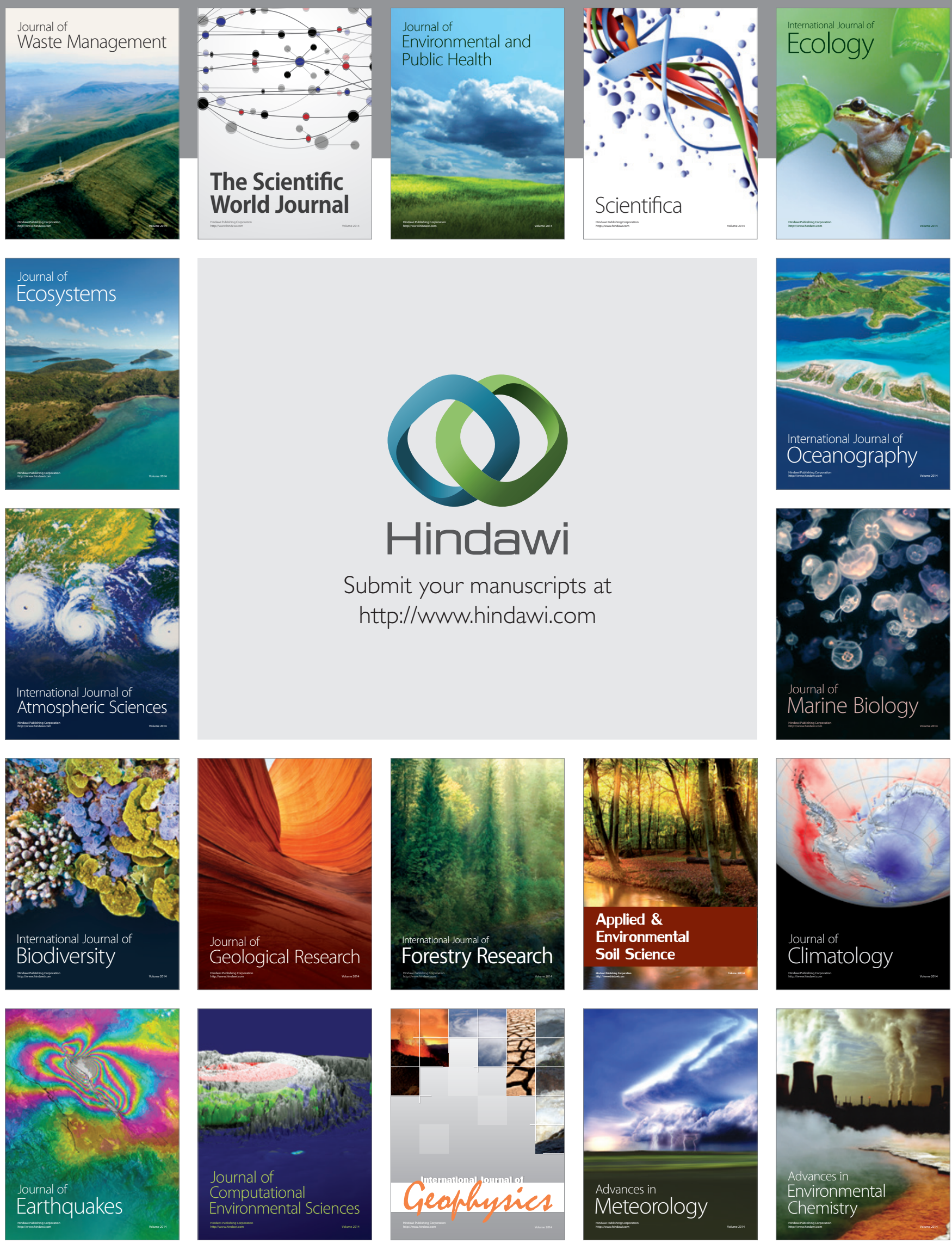